\title{
PENGARUH INFLASI DAN INVESTASI TERHADAP TINGKAT PENGANGGURAN TERBUKA DI INDONESIA TAHUN 2002-2019
}

\author{
Putri Sari M J Silaban ${ }^{1)}$, Stevi Jesika Siagian ${ }^{2)}$ \\ Fakultas Ekonomi Jurusan Pendidikan Ekonomi Universitas Negeri Medan \\ *Penulis Korespondensi: ellonagultom01@gmail.com* ${ }^{*}$ stevijesikasiagian@gmail.com
}

\begin{abstract}
Abstrak
Open Unemployment is a workforce who really doesn't have a job. This study was conducted to examine the effect of inflation and investment on open unemployment in Indonesia from 2002 to 2019. The data used are time series data. The analysis technique used in this research is multiple linear regression analysis. The results of the analysis show that inflation partially obtains a t-value of 2.142 and a significance value of $0.049<0.05$, which means that it has a positive and significant effect on open unemployment, which means that the higher the inflation, the higher the open unemployment. Investment partially obtains a t-value of -3.529 and a significance value of $0.003<0.05$, which means that it has a negative and significant effect on open unemployment, meaning that the higher the investment, open unemployment will decrease. Inflation and investment simultaneously obtain an Fcount value of 14.929 and a significance value of $0.000<0.05$, which means that it has a significant effect on open unemployment. The determination test obtained an R2-squared value of 0.666 , which means that the inflation and investment variables have a significant effect on open unemployment by 66.6 percent. From the results obtained for the government in order to maintain the stability of the inflation rate and investment so that the open unemployment rate can remain stable.
\end{abstract}

Keywords: Inflation, Investment, and Open Unemployment.

Informasi Artikel:

Artikel Diterima: 3 Juli 2020

Artikel Direvisi: 11 Agustus 2020

Artikel Disetujui: 28 Agustus 2020 


\section{PENDAHULUAN}

Masalah pengangguran merupakan masalah yang tidak pernah habis untuk diperbincangkan. Pengangguran dapat diartikan sebagai seseorang yang telah mencapai usia tertentu yang tidak memiliki pekerjaan dan sedang mencari pekerjaan agar memperoleh upah atau keuntungan. Pengangguran umumnya disebabkan karena jumlah angkatan kerja atau para pencari kerja tidak sebanding dengan jumlah lapangan kerja yang ada (Sukirno, 2004:327).

Pengangguran Terbuka merupakan salah satu klasifikasi pengangguran berdasarkan cirinya. Pengangguran Terbuka adalah tenaga kerja yang sungguh-sungguh tidak mempunyai pekerjaan. Bisa jadi karena belum mendapat pekerjaan atau memang tidak mau bekerja. Pengangguran terbuka disebabkan oleh lapangan kerja yang tidak tersedia, atau tidak adanya kecocokan antara lowongan kerja dan latar belakang pendidikan. Inflasi adalah kecenderungan dari harga-harga yang meningkat secara umum dan terus-menerus. Inflasi merupakan suatu proses kenaikkan hargaharga yang berlaku dalam perekonomian. Investasi adalah menempatkan uang atau dana dengan harapan untuk memperoleh tambahan atau keuntungan tertentu atas uang dana tersebut.

Berikut grafik tingkat pengangguran terbuka di Indonesia tahun 2002 sampai tahun 2019:

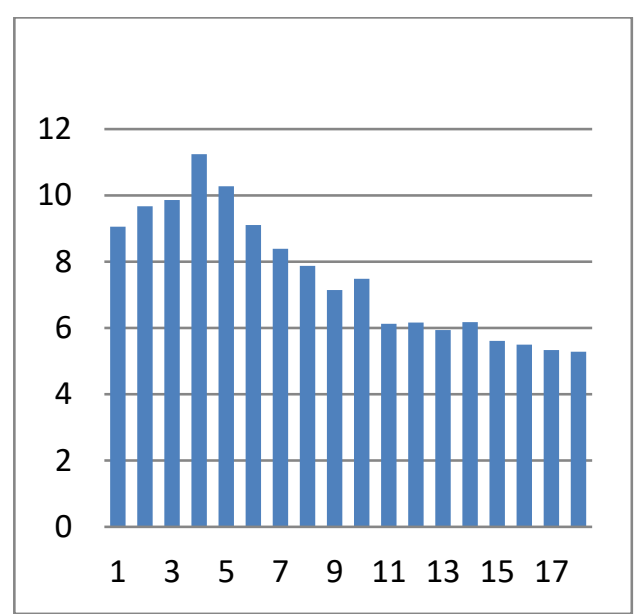

Gambar 1 Tingkat pengangguran Terbuka

Berdasarkan grafik diatas, masalah pengangguran terbuka masih saja terjadi di Indonesia pada periode 2002 sampai 2019, pengangguran di Indonesia berfluktuasi naik turun. Tahun 2002 Tingkat pengangguran Terbuka di Indonesia sebesar 9,06 persen secara tahunan diketahui meningkat sebesar 0,61 persen sehingga menjadi 9,67 persen pada tahun 2003. Hal ini disebabkan karena penyerapan tenaga kerja tidak terlaksana dengan baik dan tepat sasaran pada periode tahun 2002 sampai tahun 2003. Namun, pada tahun 2019 Tingkat Pengangguran Terbuka di Indonesia sebesar 5,28 tampak menurun sebesar 0,06 persen dari Tingkat Pengangguran Terbuka pada tahun 2018 yang sebesar 5,34 persen. Hal tersebut dapat terjadi karena penyerapan tenaga kerja yang terlaksana dengan baik dan tepat sasaran. 
Berikut grafik tingkat Inflasi di Indonesia tahun 2002 sampai tahun 2019:

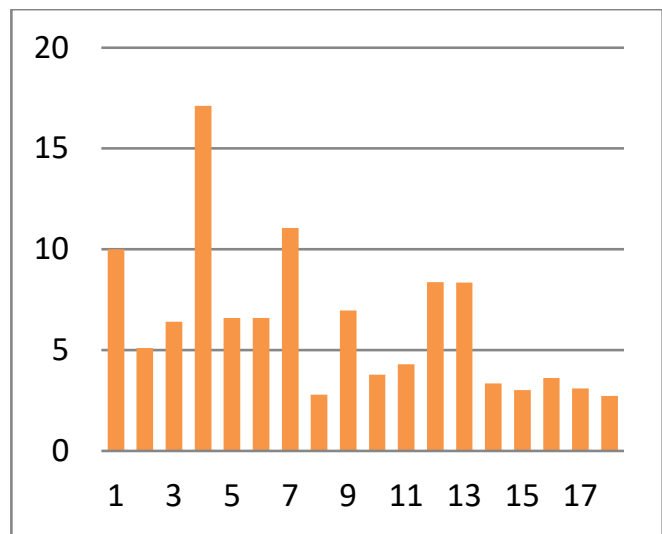

Gambar 2 Tingkat Inflasi

Berdasarkan grafik diatas, masalah tingkat Inflasi di Indonesia masih saja terjadi, pada periode 2002 sampai 2019, Inflasi di Indonesia berfluktuasi naik turun. Tahun 2002 Tingkat inflasi di Indonesia sebesar 10 persen secara tahunan menurun sangat drastis sebesar 4,9 persen menjadi 5,1 persen pada tahun 2003. Pada tahun 2005 Tingkat Inflasi di Indonesia sebesar 17,11 persen yang tampak naik secara pesat sebesar 10,71 persen dari Tingkat Inflasi pada tahun 2004 yang hanya sebesar 6,4 persen.

Berikut grafik jumlah Investasi di Indonesia tahun 2002 sampai 2019:

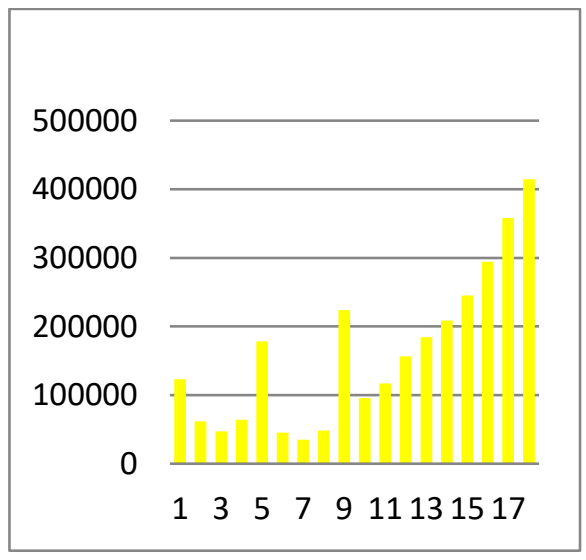

Gambar 3 Jumlah Investasi
Berdasarkan grafik diatas, masalah jumlah investasi di Indonesia masih saja terjadi, pada periode 2002 sampai 2019, Investasi di Indonesia berfluktuasi naik turun. Tahun 2002 jumlah investasi di Indonesia sebesar Rp.123.198,6 Milyar secara tahunan menurun sangat drastis sebesar Rp.61.506,6 Milyar menjadi Rp.61.692 Milyar pada tahun 2003. Pada tahun 2006 jumlah investasi di Indonesia sebesar Rp.178.391,2 Milyar yang tampak naik pesat sebesar Rp.114.234,5 Milyar dari jumlah investasi pada tahun 2005 yang hanya sebesar Rp.64.156,7 Milyar.

Menurut Philips dalam Mankiw (2000:341) berpendapat bahwa tingkat pengangguran dipengaruhi oleh tingkat inflasi. Hal itu tampak dari tingkat inflasi pada tahun 2019 sebesar 2,72 persen mengalami penurunan sebesar 0,39 persen dari tahun sebelumnya tahun 2018 sebesar 3,11 persen sehingga memberikan pengaruh yang baik terhadap Pengangguran Terbuka yang mengalami penurunan sebesar 0,06 persen.

Menurut Kurniawan (2012:5) dan Shaari et al. (2010:5), selain dipengaruhi oleh inflasi, tingkat pengangguran juga dapat di pengaruhi oleh tingkat investasi. Kurniawan (2011:5), menyatakan semakin tinggi tingkat investasi, tingkat pengangguran akan menurun. Terlihat bahwa Investasi diIndonesia juga mengalami kenaikan dari tahun 2018 sebesar 357.912,8 Milyar Rupiah menjadi 414.707,2 Milyar Rupiah pada tahun 2019 sehingga memberikan dampak positif terhadap Pengangguran Terbuka yang mengalami penurunan sebesar 0,06 persen. 
Tingkat Pengangguran Terbuka tertinggi pada tahun 2005 sebesar 11,24 persen dan Tingkat Penganguran Terbuka terendah pada tahun 2019 sebesar 5,28.

Inflasi dan Investasi merupakan dua faktor ekonomi yang sangat mempengaruhi mobilitas Pengangguran Terbuka tidak hanya di Indonesia, hal ini juga diakui oleh dunia.

\section{HIPOTESIS PENELITIAN}

Hipotesis penelitian ini untuk mengetahui pengaruh Inflasi dan Investasi terhadap Pengangguran Terbuka di Indonesia tahun 20122019.

\section{TINJAUAN PUSTAKA}

\section{Pengangguran Terbuka}

Pengangguran adalah suatu keadaan di mana seseorang yang tergolong dalam angkatan kerja ingin mendapatkan pekerjaan tetapi belum dapat memperolehnya. Seseorang yang tidak bekerja, tetapi tidak secara aktif mencari pekerjaan tidak tergolong sebagai penganggur. Pengangguran dapat terjadi disebabkan oleh tidakseimbangan pada pasar tenaga kerja. Hal ini menunjukkan jumlah tenaga kerja yang ditawarkan melebihi jumlah tenaga kerja yang diminta.

Menurut Badan Pusat Statistik (BPS) dalam indikator ketenagakerjaan, pengangguran merupakan penduduk yang tidak bekerja tetapi sedang mencari pekerjaan atau sedang mempersiapkan suatu usaha baru atau penduduk yang tidak mencari pekerjaan karena sudah diterima bekerja tetapi belum mulai bekerja.

Menurut Sadono Sukirno klasifikasi pengangguran berdasarkan cirinya, dibagi menjadi empat kelompok dan salah satunya adalah
Pengangguran Terbuka. Pengangguran terbuka adalah tenaga kerja yang sungguh-sungguh tidak mempunyai pekerjaan. Pengganguran jenis ini cukup banyak karena memang belum mendapat pekerjaan padahal telah berusaha secara maksimal dan sebagai akibat pertambahan lowongan pekerjaan yang lebih rendah daripada pertambahan tenaga kerja.

Efek dari keadaan ini di dalam suatu jangka masa yang cukup panjang mereka tidak melakukan suatu pekerjaan. Jadi mereka menganggur secara nyata dan separuh waktu, dan oleh karenanya dinamakan pengangguran terbuka. Pengangguran terbuka dapat pula wujud sebagai akibat dari kegiatan ekonomi yang menurun, dari kemajuan teknologi yang mengurangi penggunaan tenaga kerja, atau sebagai akibat dari kemunduran perkembangan suatu industri.

Tingkat pengangguran terbuka memberikan indikasi tentang penduduk usia kerja yang termasuk dalam kelompok penganggur. Tingkat pengangguran kerja diukur sebagi persentase jumlah penganggur terhadap jumlah angkatan kerja. Untuk mengukur tingkat pengangguran terbuka pada suatu wilayah bisa didapat dari presentase membagi jumlah pengangguran dengan jumlah angkatan kerja dan dinyatakan dalam persen.

Tingkat Pengangguran Terbuka (TPT) adalah angka yang menunjukkan banyaknya pengangguran terhadap 100 penduduk yang masuk kategori angkatan kerja. Pengangguran terbuka (open unemployment) didasarkan pada konsep seluruh angkatan kerja yang mencari pekerjaan, baik yang mencari pekerjaan pertama kali maupun yang sedang bekerja sebelumnya. 


\section{Inflasi}

Inflasi adalah kecenderungan dari harga-harga yang meningkat secara umum dan terus-menerus. Kenaikkan harga dari satu atau dua barang saja tidak disebut inflasi, kecuali bila kenaikkan tersebut meluas kepada sebagian besar dari harga barang-barang lain. Definisi lain mengatakan bahwa inflasi merupakan suatu proses kenaikkan harga-harga yang berlaku dalam perekonomian.

Menurut Irving Fisher dalam buku Sadono Sukirno (2002:25), kenaikkan harga-harga umum atau inflasi (P) disebabkan oleh tiga faktor yaitu jumlah uang beredar $(\mathrm{M})$, kecepatan peredaran uang (V), dan jumlah barang yang diperdagangkan (T).

Menurutnya inflasi adalah proses kenaikkan harga barang umum yang berlaku dalam perekonomian. Ini tidak berarti bahwa hargaharga berbagai macam barang itu naik dengan persentase yang sama. Yang penting terdapat kenaikkan harga-harga umum barang secara terusmenerus selama satu periode tertentu. Kenaikkan yang terjadi hanya satu sekali saja (meskipun dengan presentase yang cukup besar) bukanlah merupakan inflasi.

Veneris dan Sebol dalam Muana Nanga (2001:241) mendefinisikan inflasi sebagai suatu kecenderungan meningkatnya tingkat harga umum secara terus-menerus sepanjang waktu. Berdasarkan definisi tersebut, kenaikkan tingkat harga umum (general price level) yang terjadi sekali waktu saja, tidaklah dapat dikatakan sebagai inflasi. Dari definisi tersebut ada tiga hal penting yang ditekankan dari inflasi, yaitu:

a. Adanya kecenderungan harga-harga untuk meningkat, yang berarti bisa saja tingkat harga yang terjadi pada waktu tertentu turun atau naik dibandingkan dengan sebelumnya, tetapi tetap menunjukan tendensi yang meningkat.

b. Bahwa kenaikkan tingkat harga tersebut berlangsung secara terus-menerus (sustained), yang berarti bukan hanya terjadi pada satu waktu saja, akan tetapi bisa beberapa waktu lamanya.

c. Bahwa tingkat harga yang dimaksud disini adalah tingkat harga umum, yang berarti tingkat harga yang mengalami kenaikkan itu bukan hanya pada satu atau beberapa komoditi saja, akan tetapi untuk harga barang secara umum.

\section{Investasi}

Investasi adalah menempatkan uang atau dana dengan harapan untuk memperoleh tambahan atau keuntungan tertentu atas uang dana tersebut (Ahmad, 2004). Dari pengertian di atas dapat disimpulkan bahwa investasi adalah penyaluran sumber dana yang ada sekarang dengan mengharapkan keuntungan dimasa mendatang dengan cara menempatkan uang atau dana dalam pembelian efek berupa saham dengan harapan mendapatkan keuntungan atas dana yang diinvestasikan dalam perdagangan saham tersebut di bursa efek.

Menurut Jogiyanto (2003), investasi ke dalam aktiva keuangan dapat berupa investasi langsung dan investasi tidak langsung. Investasi langsung dilakukan dengan membeli langsung aktiva keuangan dari suatu perusahaan baik melalui perantara atau dengan cara yang lain.

Sebaliknya investasi tidak langsung dilakukan dengan membeli saham dari perusahaan investasi 
yang membeli portofolio aktiva-aktiva keuangan dari perusahaan-perusahaan lain.

\section{METODE PENELITIAN}

Metodologi penelitian yang digunakan dalam penelitian ini adalah menggunakan pendekatan kuantitatif yang berbentuk asosiatif. Tujuan penelitian kuantitatif adalah mengembangkan dan menggunakan model model matematis, teori - teori dan hipotesis yang berkaitan dengan fenomena yang diselidiki. Sedangkan, pengertian metode asosiatif adalah penelitian yang menyatakan hubungan antara dua variabel atau lebih (Sugiyono, 2009:13).

\section{Lokasi dan Waktu Penelitian}

Lokasi penelitian ini dilakukan di Sumatera Utara dengan mencari data inflasi, investasi, dan tingkat pengangguran terbuka di Badan Pusat Statistik dan buku tahunan statistik Indonesia periode 2002 sampai 2019. Dan waktu peneitian ini dilaksanakan pada 10 Mei 2020.

\section{Jenis Dan Sumber Data}

Penelitian ini menggunakan jenis data yaitu data time series antara lain data Inflasi, Investasi dan Tingkat Pengangguran Terbuka di Indonesia tahun 2002 sampai 2019. Datanya yang berbentuk laporan tahunan yang telah disusun serta diterbitkan oleh Badan Pusat Statistik (BPS).

\section{Metode Analisis Data}

Analisis statistik yang digunakan dalam penelitian ini meliputi: analisis regresi linier berganda dengan model OLS (Ordinary Least Square) guna mengetahui pengaruh antara variabel dependen yaitu tingkat pengangguran terbuka dengan variabel independen yaitu Inflasi dan Investasi.

\section{HASIL DAN PEMBAHASAN}

\section{Uji Normalitas}

Uji normalitas adalah sebuah uji yang dilakukan dengan tujuan untuk menilai data pada sebuah variabel, apakah data tersebut berdistribusi normal atau tidak. Uji Normalitas ini digunakan untuk menguji apakah variabel Inflasi, Investasi dan Pengangguran terbuka pada penelitian ini berdistribusi normal. Hasil data dari uji normalitas menggunakan alat uji SPSS 22 adalah sebagai berikut:

Tabel 1 Uji Normalitas

\begin{tabular}{|c|c|c|c|c|}
\hline & & $\begin{array}{l}\text { LOGIN } \\
F\end{array}$ & $\underset{V}{\text { LOGIN }}$ & $\begin{array}{l}\text { LOGPG } \\
\text { G }\end{array}$ \\
\hline \multirow{3}{*}{$\begin{array}{l}\text { N } \\
\text { Normal } \\
\text { Parameters }\end{array}$} & & 18 & 18 & 18 \\
\hline & $\begin{array}{l}\text { Mean } \\
\text { Std. }\end{array}$ & .7368 & 5.0952 & .8660 \\
\hline & $\begin{array}{l}\text { Deviatio } \\
\mathrm{n}\end{array}$ & 23323 & .33567 & 10922 \\
\hline $\begin{array}{l}\text { Most } \\
\text { Extreme }\end{array}$ & $\begin{array}{l}\text { Absolut } \\
e\end{array}$ & .140 & .138 & .198 \\
\hline \multirow[t]{2}{*}{ Differences } & Positive & .140 & .138 & .198 \\
\hline & Negativ & -.117 & -.124 & -.131 \\
\hline \multirow{2}{*}{\multicolumn{2}{|c|}{$\begin{array}{l}\text { Test Statistic } \\
\text { Asymp. Sig. (2-tailed) }\end{array}$}} & .140 & .138 & .198 \\
\hline & & $200^{\mathrm{c}, \mathrm{d}}$ & $200^{c, d}$ & $.059^{\circ}$ \\
\hline
\end{tabular}
a. Test distribution is Normal.
b. Calculated from data.
c. Lilliefors Significance Correction.
d. This is a lower bound of the true significance.

Berdasarkan hasil uji normalitas di atas diketahui bahwa nilai signifikansi Inflasi sebesar $0,200>0,05$, nilai signifikansi Investasi sebesar $0,200>0,05$ dan nilai signifikansi Pengangguran terbuka sebesar 0,059>0,05. Maka dapat disimpulkan data yang diolah dalam penelitian ini tidak terjadi pelanggaran uji normalitas atau penelitian ini dinyatakan berdistribusi normal.

\section{Uji Multikolinearitas}

Uji Multikolinieritas ini digunakan untuk mengetahui ada tidaknya multikolinieritas antara variabel bebas sebagai syarat analisis linier berganda dalam menguji hipotesis. Uji 
Multikolinearitas ini digunakan untuk menentukan ada atau tidaknya mutikolinearitas pada data penelitian Inflasi dan Investasi terhadap Pengangguran terbuka ini. Hasil keluaran uji Multikolinearitas yang diperoleh menggunakan alat uji SPSS 22 adalah sebagai berikut:

Tabel 2 Uji Multikolineritas

\begin{tabular}{|ll|r|r|}
\hline \multirow{2}{*}{1} & & \multicolumn{2}{|c|}{ Collinearity Statistics } \\
\cline { 3 - 4 } & & Tolerance & \multicolumn{1}{c|}{ VIF } \\
\hline & Constant) & & \\
& LOGINF & .798 & 1.253 \\
& LOGINV & .798 & 1.253 \\
\hline
\end{tabular}

Berdasarkan hasil diatas dengan diketahui bahwa nilai VIF Inflasi sebesar $1,253<10$ dan nilai VIF Investasi sebesar $1,253<10$. Maka dapat disimpulkan bahwa tidak terjadi permasalahan multikolinearitas dalam data penelitian ini.

\section{Uji Autokorelasi}

Uji Autokorelasi adalah sebuah analisis statistik yang dilakukan untuk mengetahui adakah korelasi variabel yang ada di dalam model prediksi dengan perubahan waktu. Oleh karena itu, apabila asumsi autokorelasi terjadi pada sebuah model prediksi, maka nilai disturbance tidak lagi berpasangan secara bebas, melainkan berpasangan secara autokorelasi. Pengujian Autokorelasi i akan menggunakan hasil dari Uji Run-Test.

Uji Run test merupakan bagian dari statistic non-parametrik yang dapat digunakan untuk menguji apakah antar residual terdapat korelasi yang tinggi. Pengambilan keputusan dilakukan dengan melihat nilai Asymp.Sig (2-tailed) lebih besar dari pada taraf alpha 5 persen maka akan dapat disimpulkan tidak terdapat autokorelasi pada variabel tersebut.
Tabel 3 Uji Autokorelasi

\begin{tabular}{|l|r|}
\hline & $\begin{array}{c}\text { Unstandardize } \\
\text { d Residual }\end{array}$ \\
\hline Test Value & .00212 \\
Cases < Test Value & 9 \\
Cases $>=$ Test Value & 9 \\
Total Cases & 18 \\
Number of Runs & 7 \\
Z & -1.215 \\
Asymp. Sig. (2-tailed) & .224 \\
\hline
\end{tabular}

a. Median

Berdasarkan hasil uji Run test diatas dapat diketahui bahwa nilai Asymp. Sig (2-tailed) sebesar 0,224 dimana lebih besar daripada taraf alpha sebesar 0,05. Maka dapat disimpulkan bahwa penelitian ini tidak adanya autokorelasi dalam data penelitian ini.

\section{Uji t}

Uji parsial (t-test) adalah uji yang mengukur perbedaan dua atau beberapa antarkelompok. Uji parsial atau yang dikenal dengan uji t, yaitu untuk menguji bagaimana pengaruh masing-masing variabel bebasnya secara sendiri terhadap variabel terikatnya. Uji ini dapat dilakukan dengan membandingkan t hitung dengan t tabelnya atau dengan melihat kolom signifikansinya t hitung.

Adapun hasil perhitungan uji parsial dalam hasil penelitian diatas adalah sebagai berikut:

Tabel 4 Uji t

\begin{tabular}{|c|c|c|c|c|}
\hline \multirow{2}{*}{\multicolumn{2}{|c|}{ Model }} & $\begin{array}{c}\text { Standardized } \\
\text { Coefficients }\end{array}$ & \multirow[b]{2}{*}{$\mathrm{t}$} & \multirow[b]{2}{*}{ Sig. } \\
\hline & & Beta & & \\
\hline \multirow[t]{3}{*}{1} & (Constant) & & 5.590 & .000 \\
\hline & LOGINF & .358 & 2.142 & .049 \\
\hline & LOGINV & -.590 & -3.529 & .003 \\
\hline
\end{tabular}

a. Dependent Variable: LOGPGG

Berdasarkan hasil uji parsial diatas dapat diketahui bahwa:

1) Variabel Inflasi berpengaruh positif dan signifikan terhadap pengangguran terbuka dengan perolehan nilai t hitung sebesar 2,142 dan perolehan nilai Sig 0,049<0,05, maka Ho ditolak pada taraf alpha 5 persen. 
2) Variabel Investasi berpengaruh negatif dan signifikan terhadap Pengangguran terbuka dengan perolehan nilai t hitung sebesar 3,529 dan perolehan nilai Sig $0,003<0,05$, maka Ho ditolak pada taraf alpha 5 persen.

\section{Uji F}

Uji F digunakan untuk melihat bagaimanakah pengaruh semua variabel bebasnya secara bersama-sama terhadap variabel terikatnya. Uji Simultan ini digunakan untuk menguji pengaruh variabel Inflasi dan Investasi terhadap variabel Pengangguran terbuka. Adapun hasil penelitian uji Simultan tersebut seperti dibawah ini:

\section{Tabel 5 Uji F}

\begin{tabular}{|ll|c|c|}
\hline Model & & $\mathrm{F}$ & Sig. \\
\hline 1 & $\begin{array}{l}\text { Regression } \\
\text { Residual } \\
\text { Total }\end{array}$ & 14.929 & $.000^{\mathrm{b}}$ \\
& & \\
\hline
\end{tabular}

a. Dependent Variable: LOGPGG

b. Predictors: (Constant), LOGINV, LOGINF

Pada Uji Simultan memiliki ketentuan bahwa nilai $\mathrm{F}$ hitung $>\mathrm{F}$ tabel dan nilai signifikansi < 0,05 . Berdasarkan hasil penelitian di atas diketahui bahwa nilai F hitung sebesar 14,929 dan perolehan nilai Sig. sebesar $0.000<0.05$, sehingga Ho ditolak. Disimpulkan bahwa secara simultan Inflasi dan Investasi berpengaruh signifikan terhadap Pengangguran terbuka pada taraf alpha 5 persen.

\section{Uji Koefisien Determinasi}

Koefisien determinasi bermakna sebagai sumbangan pengaruh yang diberikan variabel bebas terhadap variabel terikat. Atau dengan kata lain nilai koefisien determinasi ini berguna untuk memprediksikan dan melihat seberapa besar kontribusi pengaruh yang dberikan variabel $\mathrm{X}$ terhadap variabel $\mathrm{Y}$ secara simultan. Adapun hasil perhitungan koefisien determinasi dalam penelitian ini adalah sebagai berikut:

\section{Tabel 6 Uji Koefisien Determinasi}

\begin{tabular}{|l|l|r|r|}
\hline Model & $\mathrm{R}$ & $\mathrm{R}$ Square & $\begin{array}{c}\text { Durbin- } \\
\text { Watson }\end{array}$ \\
\hline 1 & $.816^{\mathrm{a}}$ & .666 & 1.154 \\
\hline
\end{tabular}

a. Predictors: (Constant), LOGINV, LOGINF

Berdasarkan hasil uji Determinasi diatas diketahui bahwa nilai nilai R2-squared sebesar 0,666. Hal ini menunjukkan bahwa variabel Inflasi dan Investasi berpengaruh signifikan terhadap Pengangguran terbuka sebesar 66,6 persen. Serta sisanya 33,4 persen dipengaruhi variabel lain yang tidak diteliti dalam penelitian ini.

\section{Analisis Model Regresi}

Nilai koefisien mampu menunjukkan besarnya proporsi perubahan besaran permintaan tenaga kerja industri besar sedang dalam satu satuan masing-masing variabel. Berikut nilai koefisien masing-masing variabel:

Tabel 7 Model Regresi Berganda

\begin{tabular}{|c|c|c|c|}
\hline \multirow{2}{*}{\multicolumn{2}{|c|}{ Model }} & \multicolumn{2}{|c|}{$\begin{array}{l}\text { Unstandardized } \\
\text { Coefficients }\end{array}$} \\
\hline & & $B$ & Std. Error \\
\hline & (Constant & 1.720 & .308 \\
\hline & LOGINF & .168 & .078 \\
\hline & LOGINV & -.192 & .054 \\
\hline
\end{tabular}

Adapun koefisien masing-masing variabel dapat dilihat dalam persamaan regresi penelitian seperti terlihat pada model berikut :

$\log ($ Pengangguran Terbuka $)=1,720+0,168$ $\log ($ Inflasi $)-0,192 \log ($ Investasi)

Berdasarkan koefisien diatas, maka dapat dijelaskan sebagai berikut:

a. Konstanta sebesar 1,720 menunjukkan bahwa jika variabel bebas seperti Inflasi dan Investasi 
adalah konstan, maka Tingkat Pengangguran Terbuka akan tetap sebanyak 1,720 persen.

b. Setiap kenaikan Inflasi sebesar 1 persen, maka akan meningkatkan besaran Tingkat Pengangguran Terbuka di Indonesia sebesar 0,168 persen.

c. Setiap kenaikan Investasi sebesar 1 persen, maka akan menurunkan besaran Tingkat Pengangguran Terbuka di Indonesia sebesar 0,192 persen.

\section{Pengaruh Langsung Inflasi Terhadap Tingkat}

\section{Pengangguran Terbuka Di Indonesia}

Berdasarkan hasil estimasi antara Inflasi terhadap Tingkat Pengangguran Terbuka dalam penelitian ini, secara parsial Inflasi berpengaruh positif dan signifikan terhadap Tingkat Pengangguran Terbuka. Hal ini terlihat dari koefisien variabel Inflasi sebesar 0,168 dengan nilai t-statistics sebesar 2,142 dan diperoleh nilai signifikansi sebesar 0,049 yang lebih kecil dari taraf signifikansi yang ditentukan sebesar 0,05. Hasil estimasi ini berarti ada pengaruh yang nyata antara Inflasi dengan Tingkat Pengangguran Terbuka di Indonesia dari tahun 2002 sampai 2019.

Hasil penelitian ini sesuai dengan hasil penelitian sebelumnya yang dilakukan oleh Mahanatha Giri Prayuda (2015) bahwa inflasi berpengaruh positif dan signifikan terhadap Tingkat Pengangguran Terbuka. Hasil ini juga didukung oleh penelitian Utomo (2013) bahwa terdapat pengaruh yang positif dan signifikan antara inflasi dan Tingkat Pengangguran Terbuka.

Inflasi dapat berpengaruh secara positif. Inflasi diasumsikan sebagai kenaikan permintaan. Saat terjadi kenaikan permintaan, produsen meningkatkan jumlah produksinya. Karena keterbatasan bahan baku, produsen menaikan harga produknya agar mendapatkan laba.

Saat terjadi situasi seperti itu, masyarakat akan lebih memilih barang pengganti atau substitusi dengan kualitas yang sama dengan harga yang lebih murah sehingga produsen mengalami kerugian dan banyak memecat tenaga kerjanya sehingga tingkat pengangguran terbuka menjadi meningkat.

\section{Pengaruh Langsung Investasi Terhadap Pengangguran Di Indonesia}

Pengaruh Investasi memiliki hubungan negatif dan signifikan terhadap Pengangguran di Indonesia. Hal ini terlihat dari koefisien variabel Investasi sebesar $-0,192$ dengan nilai t-statistics sebesar -3,529 dan diperoleh nilai signifikansi sebesar 0,003 yang lebih kecil dari taraf signifikansi yang ditentukan sebesar 0,05. Hasil estimasi ini berarti ada pengaruh yang signifikan antara Investasi dengan Tingkat Pengangguran Terbuka di Indonesia dari tahun 2002 sampai 2019.

Hasil penelitian ini sesuai dengan penelitian sebelumnya yang dilakukan oleh Kurniawan (2014:8) bahwa investasi berpengaruh negatif terhadap pengangguran. Apabila investasi naik satuan, maka tingkat pengangguran akan menurun sebesar satu satuan.

Hasil penelitian ini juga di dukung oleh penelitian yang dilakukan oleh Prasaja (2013) bahwa investasi berpengaruh negatif terhadap penganggguran. Meningkatnya investasi akan menciptakan permintaan dan memperbesar 
kapasitas produksi. Dengan meningkatnya kapasitas produksi maka akan banyak menyerap tenaga sehinggga tingkat pengangguran dapat terserap. Triwulan IV 2019 208,3 triliun

\section{KESIMPULAN DAN SARAN}

Dari hasil pengujian dan pembahasan diatas dapat disimpulkan bahwa secara simultan Inflasi dan Investasi berpengaruh dan signifikan terhadap Pengangguran di Indonesia dari tahun 2002 sampai 2019. Secara parsial disimpulkan bahwa variabel Inflasi berpengaruh Positif dan signifikan terhadap Pengangguran di Indonesia dan variabel Investasi berpengaruh negatif daan signifikan terhadap Pengangguran di Indonesia pada tahun 2002 sampai 2019. Variabel Inflasi dan Investasi mampu menjelaskan Pengangguran di Indonesia dari tahun 2002 sampai 2019 sebesar 66,6 persen. Hasil penelitian ini menunjukkan bahwa variabel yang signifikan dan paling dominan terhadap Pengangguran di Indonesia dari tahun 2002 sampai 2019 adalah Investasi.

\section{Saran}

Berdasarkan kesimpulan yang telah dijabarkan diatas, maka dapat disajikan saran sebagai berikut: laju inflasi dan tingkat investasi merupakan komponen yang penting dalam menekan tingkat pengangguran. Pemerintah diharapkan bisa menjaga stabilitas laju inflasi agar tetap terkendali. Dengan terjaga dan terkendalinya stabilitas laju inflasi diharapkan dapat mengatasi masalah pengangguran di Indonesia. Pemerintah juga diharapkan tetap menjaga minat para investor agar tetap berinvestasi. Dengan terjaganya minat investor untuk berinvestasi diharapkan dapat mengatasi masalah pengangguran di Indonesia.

\section{REFERENSI}

Badan Pusat Statistik. 2002. Indonesia Dalam Angka 2002. Indonesia, Jakarta.

Badan Pusat Statistik. 2005. Indonesia Dalam Angka 2005. Indonesia, Jakarta.

Badan Pusat Statistik. 2008. Indonesia Dalam Angka 2008. Indonesia, Jakarta.

Badan Pusat Statistik. 2010. Indonesia Dalam Angka 2010. Indonesia, Jakarta.

Badan Pusat Statistik. 2012. Indonesia Dalam Angka 2012. Indonesia, Jakarta.

Badan Pusat Statistik. 2015. Indonesia Dalam Angka 2015. Indonesia, Jakarta.

Badan Pusat Statistik. 2017. Indonesia Dalam Angka 2017. Indonesia, Jakarta.

Badan Pusat Statistik. 2018. Indonesia Dalam Angka 2018. Indonesia, Jakarta.

Badan Pusat Statistik. 2019. Indonesia Dalam Angka 2019. Indonesia, Jakarta.

Budiono, 2001. EKonomi Makro. Penerbit BPFE UGM-Yogyakarta.

Guretna, Elas Try. 2018. Pengaruh Pertumbuhan Ekonomi, Inflasi, Dan Investasi Terhadap Tingkat Pengangguran Di Indonesia. Universitas Muhammadiyah Surakarta, Surakarta.

http://digilib.uinsby.ac.id/3117/2/Bab\%202.pdf http://digilib.unila.ac.id/4528/15/BAB\%20II.pdf http://repo.iaintulungagung.ac.id/2336/1/BAB\%2 0II.pdf

https://www.bi.go.id//Inflasi\%20IHK\%20pada\%

20Februari\%202020,\%2C39\%25\%20(mtm). https://www.bi.go.id//Inflasi\%20IHK\%20pada\% 20Februari\%202019,\%2C39\%25\%20(mtm). 
https://www.bps.go.id/ februari-2020--tingkatpengangguran-terbuka--tpt--sebesar-4-99persen.html

https://www.bps.go.id/ februari-2019--tingkatpengangguran-terbuka--tpt--sebesar-5-01persen.html

Kurniawan, Aditya Barry. 2014. Analisis Pengaruh Pertumbuhan Ekonomi, Upah Minimum, dan Investasi terhadap Jumlah Pengangguran di Kabupaten Gesik. Jurnal Ilmiah Universitas Brawijaya, Malang.

Mankiw. 2000. Makro Ekonomi edisi keempat. Erlangga, Jakarta.

Mankiw. 2003. TEori EKonomi Makro, Alih Bahasa: Imam NUrmawan. ERlangga. Jakarta.

Nopirin. 2000. Ekonomi Moneter, BPFE UGM, Yogyakarta.

Prayuda, Giri Mahanatha dan Made Henny Urmila Dewi. 2015. Pengaruh Inflasi Dan Investasi Terhadap Pengangguran Di Provinsi Bali Tahun 1994-2013. E-Jurnal EP Unud, Bali.

Sarimuda, Tengkoe. 2014. Pengaruh PDRB, UMK, Inflasi, dan Investasi Terhadap Pengangguran Terbuka Di KAB/KOTA Provinsi Jawa Timur Tahun 2007 - 2011. Jurnal Ekonomi dan Bisnis, Jawa Timur.Shaari,

Shahidan, Mohd Ermawati Hussain, Mohd Suberi bin Ab. Halim. 2012. The Impact of Foreign Investmen on The Unemployment Rate and Economic Growth in Malaysia. Journal of Applied Sciences Reaserch.

Todaro. 2002. Pembangunan EKonomi Dunia Ketiga, Edisi Kesembilan. Erlangga. Jakarta
Utomo, Fajar Wahyu. 2013. Pengaruh Inflasi dan Upah terhadap Pengangguran di Indonesia periode tahun 1980 - 2010. Jurnal Ilmiah Universitas Brawijaya, Malang 